\title{
Correction to: Screening for natural products that affect Wnt signaling activity
}

\author{
Masami Ishibashi ${ }^{1}$ i
}

Published online: 28 June 2019

(c) The Author(s) 2019

\section{Correction to: Journal of Natural Medicines https://doi.org/10.1007/s11418-019-01320-9}

The article Screening for natural products that affect Wnt signaling activity, written by Masami Ishibashi, was originally published electronically on the publisher's internet portal (currently SpringerLink) on 30 May 2019 without open access.

With the author(s)' decision to opt for Open Choice, the copyright of the article changed on 25 June 2019 to (C) The Author(s) 2019 and the article is forthwith distributed under the terms of the Creative Commons Attribution 4.0 International License (http://creativecommons.org/licenses/ by/4.0/), which permits use, duplication, adaptation, distribution and reproduction in any medium or format, as long as you give appropriate credit to the original author(s) and the source, provide a link to the Creative Commons license and indicate if changes were made.

The original article has been updated.

Open Access This article is distributed under the terms of the Creative Commons Attribution 4.0 International License (http://creativeco mmons.org/licenses/by/4.0/), which permits unrestricted use, distribution, and reproduction in any medium, provided you give appropriate credit to the original author(s) and the source, provide a link to the Creative Commons license, and indicate if changes were made.

Publisher's Note Springer Nature remains neutral with regard to jurisdictional claims in published maps and institutional affiliations.

The original article can be found online at https://doi.org/10.1007/ s11418-019-01320-9.

Masami Ishibashi

mish@chiba-u.jp

1 Graduate School of Pharmaceutical Sciences, Chiba

University, 1-8-1 Inohana, Chuo-ku, Chiba 260-8675, Japan 